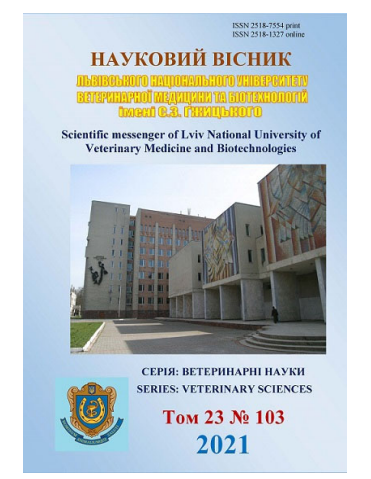

\author{
Науковий вісник Аьвівського національного університету \\ ветеринарної медицини та біотехнологій імені С.3. Гжицького. \\ Серія: Ветеринарні науки \\ Scientific Messenger of Lviv National University \\ of Veterinary Medicine and Biotechnologies. \\ Series: Veterinary sciences
}

doi: $10.32718 /$ nvlvet10317

https://nvlvet.com.ua/index.php/journal

UDC 636.5.09:616.391:615.371

\title{
Metabolic disorders in poultry (review)
}

A. Yu. Melnyk, V. S. Sakara, N. V. Vovkotrub, A. V. Kharchenko, B. P. Bilyk

Bila Tserkva National Agrarian University, Bila Tserkva, Ukraine

Article info

Received 21.07.2021

Received in revised form 23.08.2021

Accepted 24.08.2021

Bila Tserkva National Agrarian University, Bila Tserkva, pl. $8 / 1$ Soborna, 09117 Ukraine. Tel. $:+38-097-034-01-15$ E-mail: vitalii.sakara@btsau.edu.ua
Melnyk, A. Yu., Sakara, V. S., Vovkotrub, N. V., Kharchenko, A. V., \& Bilyk, B. P. (2021). Metabolic disorders in poultry (review). Scientific Messenger of Lviv National University of Veterinary Medicine and Biotechnologies. Series: Veterinary sciences, 23(103), 125-135. doi: 10.32718/nvlvet10317

The rapid growth of demand for poultry products requires its sufficient production by specialized farms of various forms of ownership. However, such production needs are not always adequate to the selection approach, the incubation component, the basic requirements of veterinary and sanitary and zoohygienic support, breed and age characteristics of keeping and raising poultry. Therefore, one of the crucial components of obtaining biologically complete, high-quality and fast-paying products of the poultry industry, including all stages of its production, is human support of the main links of ontogenesis (development after birth) of the bird. The issue of not only the creation of the genetic potential of the parent bird of different species and areas of productivity, but also the provision of veterinary and sanitary conditions for their maintenance, breeding and breeding remains relevant. However, the current economic conditions have forced the heads of enterprises and veterinary departments to some extent bypass the planned laboratory tests of feed, water and blood, which, although not complete, but informative enough to trace the main periods of growth and development of the bird. Slight deterioration of the mode and quality of feeding, changes in the parameters of the microclimate are reflected in changes in blood parameters. And what about the spoilage of feed, water, violation of veterinary and sanitary maintenance of poultry: the lack of preventive treatments with vitamin-mineral, hepatoprotective and enzyme preparations, pre- and probiotics. Which can lead to metabolic disorders in poultry. Which can occur due to disorders of protein, lipid, carbohydrate, vitamin, macro- and micromineral metabolism. As a result, there are significantly popular diseases such as: uric acid diathesis, cannibalism, osteoporosis and osteomalacia, perosis, rickets, obesity, E-hypovitaminosis. Further reducing productivity, which leads to large economic losses on farms.

Key words: broiler chickens, laying hens, Zinc, Manganese, Vitamin A, Vitamin D.

\section{Порушення метаболізму в сільськогосподарської птиці (огляд)}

\author{
А. Ю. Мельник, В. С. Сакара, Н. В. Вовкотруб, А. В. Харченко, Б. П. Білик \\ Білоиерківський національний аграрний університет, м. Біла Церква, Украйна
}

\begin{abstract}
Стрімке зростання попиту на продукиію галузі птахівництва вимагає ї̈ достатнього виробництва спеціалізованими господарствами різних форм власності. Проте така виробнича необхідність не завжди адекватна селекційному підходу, інкубаційній складовій, основним вимогам ветеринарно-санітарного та зоогігієнічного забезпечення, порідним і віковим особливостям утримання та вирощування птиці. Тому однією із вирішальних складових отримання біологічно повноцінної, якісної та швидкоокупної продукиї галузі птахівництва, включаючи усі етапи ї̈ отримання, залишається супровід людиною основних ланок онтогенезу (розвитку після народження) птаха. Актуальним залишається питання не тільки створення генетичного потенціалу птиці батьківського поголів'я різних видів і напрямів продуктивності, а й забезпечення ветеринарно-санітарних умов з їхнього утримання, вирощування і розведення. Однак нинішні економічні умови змусили керівників підприємств та ветеринарних підрозділів деякою мірою оминати планові лабораторні дослідження кормів, води та крові, які хоч і не повною мірою, проте достатньо інформативно дають змогу простежувати основні періоди росту і розвитку птаха. Незначне погіршення режиму та якості годівлі, зміна параметрів мікроклімату відображаються на зміні показників крові. А що ж говорити про псування кормів, води, порушення ветеринарно-санітарного забезпечення утримання птиці: відсутність профілактичних обробок вітамінно-мінеральними, гепатопротекторними та ферментними препаратами, пре- та пробіотичними засобами. Все це може призвести до порушення обміну
\end{abstract}


речовин в сільськогосподарської птиці. Вони можуть виникати через порушення білкового, ліпідного, вуглеводного, вітамінного, макро- та мікромінерального обмінів, у результаті яких виникають захворювання: сечокислий діатез, канібалізм, остеопороз та остеомалячія, пероз, рахіт, ожиріння, Е-гіповітаміноз. В подальшому знижується продуктивність, щио призводить до великих економічних збитків на господарствах.

Ключові слова: курчати-бройлери, кури-несучки, Цинк, Манган, вітамін А, вітамін D.

Вступ

Обмін речовин - це сукупність процесів перетворення речовин і енергії в організмі, які забезпечують його життєдіяльність у взаємозв'язку із зовнішнім середовищем. Для птиці, порівняно з сільськогосподарськими тваринами інших видів, притаманний високий рівень обмінних процесів, які забезпечуються адекватною годівлею (Swennen et al., 2007). Висока продуктивність птиці завжди пов'язана з достатньою калорійністю комбікормів, якісними білкововітамінними преміксами та мінеральними добавками (Poureslami et al., 2010). Тому й хвороби, спричинені порушенням обміну речовин, зумовлені в основному дефіцитом або надлишком енергії, окремих поживних i біологічно активних речовин (Liu et al., 2015).

Поживні речовини корму всмоктуються у вигляді амінокислот, жирних кислот, гліцеролу, моноцукрів, летких жирних кислот, води, солей та інших сполук. $\mathrm{У}$ результаті біохімічних реакцій із них у клітинах синтезуються енергія і пластичний матеріал. Варто зазначити, що у процесі окиснення 1 г вуглеводів виділяється в середньому 4,1 ккал (близько 17,2 кДж) енергії. Це в 1,25 і 2,25 раза менше, ніж за окиснення 1 г білків або жирів відповідно. Незважаючи на це, тварини насаперед для отримання енергії використовують вуглеводи (Pineda et al., 2012).

В організмі птиці всі види обміну речовин тісно взаємопов'язані, тому будь-яке захворювання спричиняє порушення гомеостазу, однак провідним у виникненні хвороби $є$ порушення одного або двох видів обміну. Метаболічні хвороби у птиці займають близько 90 \% усієї незаразної патології (Kras et al., 2013).

Хвороби, спричинені порушенням обміну речовин, умовно поділяють на чотири групи.

До периої належать хвороби, які переважно спричинені порушенням вуглеводно-ліпідного і білкового обміну. Найактуальнішими для птиці варто назвати аліментарну дистрофію та ожиріння (Swennen et al., 2007).

Друга група включає захворювання, зумовлені порушенням обміну макроелементів. Ця категорія хвороб притаманна безпосередньо високопродуктивним курям-несучкам, оскільки обмін Кальцію і Фосфору в них проходить найінтенсивніше серед відомих представників тваринного світу. Гіпокальціємія та гіпофосфатемія у клінічну стадію свого розвитку діагностуються як остеопороз і остеомаляція курей-несучок або ж “клітковий параліч” (Sakara et al., 2019).

Третя група об'єднує хвороби, що спричинюються нестачею або надлишком мікроелементів - мікроелементозами. До них належать: недостатність Цинку, Мангану, Селену гіпокобальтоз, гіпокупроз, а також хвороби, спричинені надлишком Бору, Нікелю, Молібдену та Селену (Sakara et al., 2019).
Четверту групу складають гіповітамінози. Це хвороби, які виникають внаслідок нестачі ретинолу, холекальциферолу, токоферолу, вітамінів групи В, аскорбінової кислоти, філохінону. Значно рідше у тварин виникають гіпервітамінози. Останнім часом велику увагу приділяють дозозалежному впливу вітамінів на організм птиці (Halle \& Ebrahem, 2012).

Найчастіше в господарствах різних форм власності трапляється поєднаний перебіг захворювання, що вченими розглядається як поліметаболічна або поліморбідна патологія. Водночас у високопродуктивних кросів курей-несучок можуть перебігати A-, D- i Eгіповітамінози, пероз та $\mathrm{B}_{1}$-гіповітаміно3, жирова дистрофія печінки і сечокислий діатез, нефрит та остеодистрофія, гепатодистрофія й остеопороз і т. д. (Swennen et al., 2007).

Стандартні схеми лікування птиці 3 порушенням обміну речовин малоефективні, оскільки не враховують видових та індивідуальних особливостей організму, ступеня ураження окремих органів і систем (Mel'nyk, 2011).

3 огляду на вищенаведене, актуальним є питання не тільки створення генетичного потенціалу птиці батьківського поголів'я різних видів і напрямів продуктивності, а й вивчення внутрішньої патології у птиці різних видів, забезпечення ветеринарносанітарних умов їх утримання, вирощування і розведення. Одним із таких напрямів діяльності вітчизняних науково-дослідних та виробничих установ є розробка методів диспансеризації сільськогосподарської птиці з метою комплексного підходу до ранньої діагностики метаболічних хвороб.

\section{Результати та їх обговорення}

Доцільно зупинитися на короткій характеристиці порушень метаболічного статусу в курей-несучок, які до субклінічного (доклінічного) прояву складно діагностувати клінічними методами дослідження.

Ожсиіння - надлишкове відкладання жиру у підшкірній клітковині та інших тканинах організму, міжклітинних проміжках. Розрізняють екзогенне, або аліментарне, та ендогенне (ендокринне) ожиріння (Clarke, 2008; Mohiti-Asli et al., 2012).

Аліментарне ожиріння спричиняється надлишковим енергетичним живленням птиці. Найчастіше хворіє птиця до періоду яйцекладки (130-140 доба), особливо за високого (понад 300 ккал) вмісту в раціоні обмінної енергії. Ендогенне ожиріння притаманно курям-несучкам, які досягли піку яйцекладки, оскільки забезпечення високої (95-98 \%) продуктивності вимагає працювати усі органи і системи на межі можливостей (Lin et al., 1980). Наслідком цього є порушення основного обміну і ліполізу, яке спричиняється нестачею тиреоїдних гормонів та компенсаторних 
можливостей гіпоталамо-гіпофізарної системи. За нормами високопродуктивні кроси курей-несучок зарубіжної та вітчизняної селекції у віці 32-48 тижнів потребують 260-290 ккал обмінної енергії. За ожиріння вміст холестеролу в сироватці крові курейнесучок збільшується до 5-7 ммоль/л (Fouad et al., 2012; Chen et al., 2017).

Аліментарна дистрофія - захворювання, яке виникає за дефіциту поживних речовин в раціоні або голодуванні, внаслідок чого порушується обмін речовин, з'являються дистрофічні й атрофічні зміни в органах та системах 3 подальшим порушенням їніх функцій (Bozakova et al., 2012). Птиця втрачає близько 40 \% маси тіла, виявляють атрофію м'язів, аптеріоз та набряки у ділянці підгрудка і вентральної частини черевної стінки. У сироватці крові вміст загального білка менше ніж 43 г/л (гіпопротеїнемія) (Alloui \& Bouzouaia, 2015).

Кальціє-фосфорний обмін в організмі курейнесучок займає особливе місце. Формування шкаралупи яйця вимагає оновлення цього обміну в крові не менше чотирьох разів за годину (у ВРХ один раз на добу) (Proszkowiec-Weglarz \& Angel, 2013). Тому i порушенню метаболізму цих макроелементів приділяється значна увага. Проте важливе значення у процесах засвоєння та використання Кальцію і Фосфору в організмі птиці має вітамін $\mathrm{D}_{3}$, а точніше його активні метаболіти: $25 \mathrm{OHD}_{3}, \quad 1,25(\mathrm{OH})_{2} \mathrm{D}_{3}$ та $24,25(\mathrm{OH})_{2} \mathrm{D}_{3}$ (Bar et al., 2003). Вітамін $\mathrm{D}_{2}$ такого практичного значення не має, оскільки його активність у 30 разів $є$ меншою, ніж вітаміну $\mathrm{D}_{3}$. Виходячи з цього, розглядати обмін Кальцію і Фосфору, не беручи до уваги вітамін $\mathrm{D}_{3}$, є недоцільним (Pelicia et al., 2009). До активних регуляторів кальцієвого гомеостазу належать: паратгормон (паратерин, ПТГ), кальцитонін (КТ), кальцитріол, опосередковану дію мають естрадіол, прогестерон, трийодтиронін $\left(\mathrm{T}_{3}\right)$ та тироксин ( $\left.\mathrm{T}_{4}\right)$ (Li et al., 2017).

D-zіповітаміноз (D-hypovitaminosis) - хронічне захворювання птиці усіх видів, зумовлене розладом D-вітамінного і фосфорно-кальцієвого обміну речовин (Burgos et al., 2006). Вітамін $\mathrm{D}_{3}$ на відміну від вітаміну А накопичується в організмі в невеликих кількостях, тому ознаки D-вітамінної недостатності проявляються вже на 2-3 тиждень життя (Mattila et al., 2011).

У переважній більшості порушення фосфорнокальцієвого і D- вітамінного обмінів у птиці проявляються остеопорозом та остеомаляцісю, а у молодняку - paximoм (Peters \& Martini, 2010; Świątkiewicz et al., 2017).

Paxim - хронічне захворювання молодняку птиці всіх видів, яке виникає за нестачі в раціонах Кальцію, Фосфору та вітаміну $\mathrm{D}_{3}$ або ж спричиняється порушенням їхнього обміну в організмі (Oviedo-Rondón et al., 2006; Dinev, 2011). В основі патоморфологічної картини рахіту лежить первинна затримка росту кісткової тканини з порушенням метаболізму Кальцію, Фосфору, вітаміну D та відставання процесу мінералізації від фізіологічних потреб ростучого організму (Dinev, 2012a; 2012b; 2012).
Остеопороз - це системне захворювання скелету, яке характеризується зменшенням маси кістки в одиниці ії об’єму, порушенням мікроархітектоніки трабекул і збільшенням кількості переломів (Rath et al., 2000; Whitehead \& Fleming, 2000; Fleming et al., 2006).

Остеомаляція - хронічно перебігаюча безлихоманкова хвороба дорослої птиці, яка характеризується вторинним розсмоктуванням i метапластинчатою реконструкцією кісткової тканини, що закінчила ріст, 3 переважним порушенням фосфорно-кальцієвого і Dвітамінного обмінів (Manohar \& Kanagaraju, 2015).

Найбільш небажаним наслідком порушення Dвітамінного i фосфорно-кальцієвого обмінів є зниження якості шкаралупи яєць. Відхід яєць від пошкоджень шкаралупи у країнах СЕС, США і Канаді сягає 1-10, а інколи - $15 \%$. Фінансові втрати господарств від прояву в курей-несучок остеопорозу становлять не менше 3-6 \% за кожен місяць експлуатації у продуктивний період (Sparke et al., 2002; Akbaş et al., 2009; Dinev, 2012).

Лабораторна діагностика за усіх перерахованих форм порушень фосфорно-кальцієвого обміну має свої особливості, проте для початкової стадії захворювання притаманним $є$ зниження у сироватці крові курей передпродуктивного періоду вмісту загального Кальцію до 2,0 ммоль/л (Bradshaw et al., 2002). Водночас на піку яйцекладки вміст загального Кальцію, неорганічного Фосфору та активність ізоферментів лужної фосфатази у сироватці крові мають становити відповідно $6,0-9,5, \quad 1,74-2,20$ ммоль/л та 440650 Од/л. Вміст Кальцію та Фосфору в сухій знежиреній кістці - 22,4 та 10,1 мг/100 г відповідно. Потреба високопродуктивних курей-несучок у вітаміні $\mathrm{D}_{3}$ залежно від інтенсивності яйцекладки має становити від 2 до 3,5 тис. МО/кг комбікорму, Кальцію 3-4,2 та Фосфору 0,7-8 г/100 г корму (Levchenko et al., 2016).

A-zinoвітаміноз (A-hypovitaminosis) - хронічне захворювання, спричинене нестачею в організмі ретинолу або його провітаміну - каротину. Характеризується посиленою метаплазією й ороговінням епітеліальних клітин шкіри, слизових оболонок дихальних шляхів, травного каналу, сечостатевих органів, порушенням зору, відтворної функції та росту молодняку (рис. 2). А-гіповітаміноз - широко поширене захворювання дорослих тварин всіх видів та молодняку. Основна кількість вітаміну А міститься у печінці птиці, невелика кількість - у жовтках яєць (Reznichenko et al., 2017).

На відкладання вітаміну А в печінці впливають вміст його в раціоні та ступінь абсорбції в кишечнику.

Розрізняють первинний i вторинний Агіповітаміноз.

Первинний A-гіповітаміноз виникає у молодняку до двотижневого віку внаслідок неповноцінності жовтків яєць за вмістом ретинолу (менше 6 мкг/г) або каротиноїдів, недостатнього надходження ретинолу і каротину з кормами та дефіциту в раціоні протеїну, цукру, Co, Zn та J (Cortes et al., 2006).

Вторинний А-гіповітаміноз - спричиняється хворобами печінки, кишечнику, гіпотиреозом, руйнуван- 
ням вітаміну А нітритами, хлоридами нафталіну, іншими антивітамінами (Fan et al., 2015).

Так, у курчат виведених із яєць 3 низьким рівнем вітаміну А, ознаки А-гіповітамінозу проявляються вже в кінці першого тижня життя, а у виведених 3 повноцінних яєць - до 40-50 дня життя (Dalloul et al., 2002).

У молодняку за нестачі вітаміну А симптоми проявляються через 3-4 тижні, а у дорослої птиці - 2-3 місяці (Abudabos et al., 2013; Fan et al., 2015).

Ступінь забезпечення птиці вітаміном А визначають за вмістом у печінці, жовтках інкубаційних яєць та сироватці крові. Так, вміст ретинолу в печінці дорослих курей має становити не менше ніж 300 мкг/г, у добових курчат - не менше 20-30 мкг/г, а у жовтках інкубаційних яєць - 6-8 мкг/г. Водночас у сироватці крові птиці під час яйцекладки вітаміну А - 150 230 мкг/100 мл. Потреба курей-несучок у вітаміні А має бути в межах 10-12 тис. МО/кг комбікорму (Reznichenko et al., 2017; Çevİk, 2018).

E-zіповітаміноз (E-hypovitaminosis) - захворювання, що виникає у разі недостатнього надходження в організм вітаміну Е (токоферолу) та супроводжується енцефаломаляцією, міодистрофією або ексудативним діатезом (Romanovych et al., 2018).

Нестача вітаміну Е найчастіше виникає у молодняку птиці 10-15-добового віку. За нестачі токоферолу і надлишку жирів у раціоні 2-6-тижневі курчата хворіють на енцефаломаляцію (розм'якшення мозку) (Nawab et al., 2018). Симптомами цього захворювання $\epsilon$ порушення координації рухів, судоми, витягнута шия, закинута назад або вивернута набік голова. Також, окрім енцефаломаляції, нестача в кормах токоферолу спричиняє у птиці м'язову дистрофію 3 некрозом м'язових волокон, ексудативний діатез, який супроводжується набряками і крововиливами в підшкірну клітковину внаслідок підвищеної проникності судинної стінки (Parolini et al., 2015; Dalia et al., 2018). В нормі вміст вітаміну Е у сироватці крові курей-несучок має бути в межах 0,9-1,0 мг/100 мл, печінці - 10-16 мкг/г, жовтках інкубаційних яєць - 70-200 мкг/г. Потреба дорослих курей-несучок у токоферолі становить 10 30 мг/кг комбікорму (Lin et al., 2005).

Зазвичай недостатність або надлишок білків, жирів, вуглеводів, вітамінів, макро- та мікроелементів або ж хвороби внутрішніх органів, у яких проходить метаболізм цих речовин, спричиняє виникнення поліетіологічних захворювань (поліметаболічна патологія). Однією з таких хвороб, яка наносить значні економічні збитки птахівництву, $є$ сечокислий діатез (Abou-Elela, 2017).

Сечокислий діатез (подагра, сечокам'яна хвороба) - хронічне захворювання птиці, пов'язане з порушенням обміну речовин, головним чином білкового i фосфорно-кальцієвого, яке супроводжується підвищеним утворенням сечової кислоти, дисфункцією клубочків і канальців нирок, ураженням сечовивідних шляхів і відкладанням уратів у внутрішніх органах, вісцеральних поверхнях та суглобах (Hada et al., 2013; Abou-Elela, 2017).
Кури-несучки високопродуктивних порід хворіють переважно у віці 100-180 діб. Однак останнім часом почастішали випадки прояву сечокислого діатезу у 13-добових курчат, загибель яких від захворювання складає близько 70 \% (Nischemenko et al., 2019).

У деяких господарствах загибель 30-40 \% поголів'я спричиняє лише подагра (суглобова форма сечокислого діатезу). Основними причинами захворювання $є$ тривала надмірна (більше ніж 17 \%) протеїнова годівля, згодовування кормів, що містять велику кількість нуклеїнових кислот (м'ясо-кісткове, кров'яне i рибне борошно). Зазвичай передчасне переведення молодняку на предкладковий раціон курей-несучок $\epsilon$ однією з причин розвитку захворювання. Недостатність вітамінів А і С, гіподинамія птиці, хронічні мікотоксикози, нефропатогенні штами інфекційного бронхіту курей, хвороби нирок призводять до виникнення сечокислого діатезу різних форм, зокрема подагри, коли солі сечової кислоти відкладаються у капсули суглобів (Levchenko et al., 2016).

Розрізняютьтакі форми сечокислого діатезу: вісцеральна - уражаються серозні покриви і внутрішні органи (серце, печінка, нирки, м'язи); суглобова урати відкладаються переважно у капсулі суглобів (подагра), змішана - вісцерально-суглобова та локальна - переважно у нирках і сечопроводах. Зазвичай лікування птиці, хворої на сечокислий діатез, є малоефективним, оскільки морфологічні зміни, що розвиваються у внутрішніх органах, у своїй переважній більшості мають незворотний характер (Moyle et al., 2011).

Одним із ранніх інформативних тестів, який вказує на доклінічний розвиток захворювання, є визначення у сироватці крові птиці вмісту сечової кислоти, яка в нормі має становити 0,12-0,42 ммоль/л за концентрації загального білка 43-60 г/л. У віці 21-45 тижнів високопродуктивні кроси курей-несучок мають отримувати не більше ніж 17,5 г сирого протеїну на 100 г комбікорму за вмісту Кальцію і Фосфору 3,6 та 0,7 відповідно (Moyle et al., 2011).

Нестача у кормах птиці вітаміну $\mathrm{B}_{4}$ та марганцю призводить до виникнення у молодняку перозу (недостатність баліневрину або аматину, марганцева недостатність), а в дорослої птиці - жовткового перитоніму $\boldsymbol{i}$ гепатодистрофіi. Пероз характеризується деформацією та вивертанням суглобів, порушенням процесу формування кісток, зв'язкового апарату з подальшими змінами анатомічного розміщення ахілового сухожилля (виходить зі свого виростка, стопа повертається під прямим кутом, подібно до вивиху кінцівок). Тому холін у птахівництві отримав назву “антиперозного” фактора, що супроводжується розладами функції кінцівок (“ковзний” суглоб, “ковзне" сухожилля) (Farina et al., 2017; Ognik et al., 2019).

Розвиток цього захворювання спричиняє нестача біотину, ніацину, рибофлавіну, фолієвої кислоти, ціанокобаламіну, а також неправильне співвідношення у раціоні кислих і лужних еквівалентів, надлишок Йоду і Молібдену - антагоністів марганцю (Priyanka et al., 2018). 
У дорослої птиці нестача холіну призводить до виникнення дистрофії печінки та жовткового перитоніту. Гепатодистрофія розвивається внаслідок зменшення синтезу холінофосфатидів (лецитини), які забезпечують постійний відплив тригліцеридів із печінки у кров'яне русло і запобігають розвитку жирової дистрофії гепатоцитів. Таким чином, холін проявляє ліпотропну дію. Своєю чергою холін входить до складу фосфоліпідів, які беруть участь в утворенні біологічних мембран (Edwards, 2000). Утворення ацетилхоліну напряму пов'язане з наявністю в організмі птиці холіну, він $є$ вихідною речовиною для його синтезу і джерелом метильних груп, що необхідні організму для синтезу метіоніну, креатину, адреналіну. Контроль забезпеченості організму птиці у холіні здійснюють за визначенням його вмісту у печінці $-4,4$ 7,9 мкг. Жовток курячих яєць містить 175-308 мг холіну, а в 1 г сухої речовини цілого яйця його міститься 1,6 мг. У білку яєць холін практично відсутній. Програми з утримання курей-несучок передбачають введення різної його кількості, але в межах від 500 до 1050 г/т комбікорму (Selvam et al., 2018).

Одним із захворювань, 50 \% етіологічних чинників якого останнім часом розглядається 3 позицій порушення обміну речовин, є канібалізм (розкльов). Однак цей фізіологічний стан вважають не хворобою, а реакцію пернатих на умови утримання. Нерідко розкльов виникає після посадки нової групи птахів у стадо зі сформованим порядком. Інтенсивне освітлення курочок на початку яйцекладки викликає розкльов у ділянці клоаки, оскільки клоачне кільце напружене і добре помітні кровоносні судини. Поява крові привертає увагу інших курей і може слугувати початком розкльову. Захворювання може виникнути внаслідок порушення годівлі птахів. Важливе місце в етіології канібалізму відводиться білковому обміну. Гострий дефіцит білка в раціоні або інтенсивне нетривале (710 днів) перегодовування білками тваринного походження з подальшим виключенням тваринних кормів 3 раціону майже завжди призводить до масового розкльову. Канібалізм пов'язаний не тільки із загальним білковим обміном, а головним чином 3 амінокислотним складом білка. Основна роль відводиться незамінним амінокислотам (метіоніну, цистину, аргініну, триптофану, фенілаланіну, тирозину), які є вихідним матеріалом для біосинтезу гормонів, ферментів і вітамінів. Так, при зниженні в раціоні аргініну з 6,9 до 3,9 \% від загального білка у птахів спостерігається поїдання пера і виникнення канібалізму. Порушення мікроклімату може бути однією з причин канібалізму. Інтенсивне освітлення за кліткового утримання курчат і одноманітного годування призводить до частих проявів розкльову. Загибель курей-несучок на піку яйцекладки може становити до 30 \% (Lambton et al., 2015).

Велику групу хвороб поліметаболічної етіології складають захворювання, спричинені порушенням обміну водорозчинних вітамінів, до яких належать вітаміни групи $\mathrm{B}\left(\mathrm{B}_{1}, \mathrm{~B}_{2}, \mathrm{~B}_{3}, \mathrm{~B}_{5}, \mathrm{~B}_{6}, \mathrm{~B}_{\mathrm{c}}, \mathrm{B}_{12}\right.$, вітаміни $\mathrm{H}$, $\left.\mathrm{C}, \mathrm{B}_{4}\right)$. У хімічному значенні вітаміни групи $\mathrm{B}$ об'єднує те, що всі вони містять Азот, тобто відпові- дають терміну “вітамін”, у біологічному - вони беруть участь у побудові молекул коферментів (кофермент - небілкова частина ферментів). Тому нестача або ж порушення їхнього обміну в організмі призводить до дисфункції інших видів обміну (білкового, вуглеводного, ліпідного, вітамінно-мінерального).

Останнім часом, особливо у приватних фермерських господарствах, почастішали випадки масової загибелі молодняку птиці, особливо водоплавної, 3 клінічними симптомами В-вітамінної недостатності різної етіології (рис. 5). Трапляються випадки загибелі 90 \% поголів'я молодняку до 15-добового віку 3 клінічним проявом $\mathrm{B}_{1-}, \mathrm{B}_{2}$ та $\mathrm{B}_{6}$-гіповітамінозів. У курейнесучок клінічний прояв нестачі вітамінів групи В проявляється не так часто, проте виводимість та збереженість молодняку, отриманого від поголів'я птиці, яка утримувалась на дефіцитних за В-вітамінним складом раціонах, дуже низькі (Drinić et al., 2016).

Водночас варто зупинитись на короткій характеристиці патогенетичних факторів прояву порушень обміну вітамінів групи В.

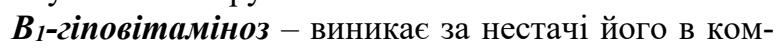
бікормі, надмірного згодовуванні вуглеводистих кормів після їх зігрівання, підвищенні лужності кормів, згодовуванні кормів, які містять велику кількості антивітамінів - окситіамін (бобові) та фермент тіаміназу. За нестачі тіаміну в організмі птиці розвивається захворювання - поліневрит, хоча думки вчених щодо цього є суперечливими. За нестачі тіаміну в клітинах головного мозку порушується вуглеводний обмін, зменшується перетворення піровиноградної кислоти і включення іiї в цикл Кребса (Sifri, 1995). У клітинах нагромаджуються піровиноградна, молочна та гліоксалова кислоти, які мають токсичний вплив на мозкову тканину. Це проявляється в прогресуючій дегенерації нервових закінчень і провідних пучків, наслідком чого $є$ некроз нейронів (кортико-церебральний некроз). В результаті спостерігається втрата шкірної чутливості, настає порушення функції серцевосудинної системи, органів травлення, водного обміну. У хворих виявляють атаксію, судоми, під час яких голова птиці закидається на спину, кінцівки притискуються до живота, а хвіст піднімається. Зрештою настає параліч і смерть (Greenacre, 2015).

Але частіше $\mathrm{B}_{1}$-гіповітаміноз проявляється задишкою, слабкістю, швидкою стомлюваністю, втратою апетиту, зниженням опірності до інших захворювань і т. д. До складу комбікорму вітамін $\mathrm{B}_{1}$ вводять у кількості не менше ніж 2 г/т комбікорму (Berger \& Shenkin, 2006).

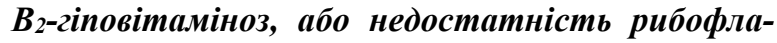
$\boldsymbol{в} \boldsymbol{i н y}$ - хронічне захворювання птиці, яке супроводжується порушенням енергетичного обміну (тканинне дихання), біосинтезу амінокислот - метіоніну, триптофану, лізину та обміну вітамінів - пантотенової кислоти, холіну піридоксину, фолієвої та оротової кислот, синтезу вітаміну $\mathrm{B}_{12}$. За нестачі рибофлавіну знижується активність багатьох ферментних систем організму, що зумовлює порушення обміну білків, вуглеводів, ліпідів, виділяється багато амінокислот, унаслідок чого розвивається негативний азотистий 
баланс, який проявляється виснаженням тварин і затримкою їхнього росту (Нocking et al., 2013). Характерною ознакою $\mathrm{B}_{2}$-гіповітамінозу є розвиток аптеріозу, алопецій, дерматиту, виразок у ротоглотці й шлунково-кишковому каналі, кератиту, кон'юнктивіту, васкуляризації рогівки (кров'янисте око). У птахів розвивається м'язова слабкість, парези крил, виявляють розлад координації рухів, скорчуються пальці кінцівки. Об'єктивним показником патології $є$ вміст рибофлавіну в яйцях. У білку яєць курей його має бути 2-3, у жовтку - 3-5 мкг/г. Вміст рибофлавіну в комбікормі для курей-несучок становить близько 5 6 г/т (Cai et al., 2006).

Вз-гіповімаміноз, або недостатність пантотенової кислоти (нестача антидермічного фактора) хронічна хвороба, яка супроводжується порушенням ліпідного, білкового, вуглеводного та енергетичного обмінів і характеризується патологічними змінами в шкірі, спинному мозку, шлунково-кишковому каналі, органах кровотворення, надниркових залозах, порушенням яйцеутворення і сперматогенезу (Sakara \& Melnyk, 2019). Вплив вітаміну В 3 на обмін речовин пов'язаний з тим, що він входить до складу коензиму А (коферменту А). Цьому коферменту належить провідна роль у функціонуванні циклу трикарбонових кислот, синтезі ацетилхоліну, стероїдних гормонів, жовчних кислот, синтезі та окисненні жирних кислот, фосфоліпідів, утворенні кетонових тіл. Найчастіше трапляється у птиці, оскільки вона споживає мало трави і біосинтез вітаміну $\mathrm{B}_{3}$ у травному каналі не відбувається. Безконтрольне застосування антибіотиків пригнічує мікрофлору травного тракту, а отже - й біосинтез вітаміну. Проявляється хвороба дерматитами, насамперед на кінцівках, пізніше - навколо дзьоба і очей та паралічами. У плазмі крові курей пантотенової кислоти має міститися не менше ніж 50 мкг/100 мл, а яйці - 9 мкг/г. Вміст вітаміну $\mathrm{B}_{3}$ у комбікормах для курей-несучок залежно від віку та фізіологічного стану має становити від 5,5 до 20 г/т (Wang et al., 2016).

В5-гіповітаміноз, або недостатність нікотинової кислоти - хронічне захворювання, що характеризується порушенням білкового, жирового і вуглеводного обмінів, трофіки і кольору шкіри (пелагра - шершава шкіра) і розвитком запальних і виразково-некротичних процесів у шлунково-кишковому каналі. Вплив вітаміну $\mathrm{B}_{5}$ на обмін речовин полягає в тому, що він, зв'язуючись 3 нуклеотидами, утворює два коферменти: нікотинамідаденіндинуклеотид (НАД) і нікотинамідаденіндинуклеотидфосфат (НАДФ) (Karthikeyan \& Thappa, 2002).

У сполуці зі специфічним протеїном (апоферментом) обидва коферменти беруть участь більш як у 150 реакціях розщеплення вуглеводів, жирів, окисненні спиртів, амінокислот. Недостатність нікотинової кислоти спричинює порушення росту епідермісу, пір'я, виникає лусочковий дерматит. Згодом у хворих знижується секреторно-ферментативна функція шлунково-кишкового каналу, еритроцитопоез, пригнічується фагоцитарна активність нейтрофілів. За тяжкого перебігу хвороби слизова оболонка ротової порожнини, язика, початкової частини стравоходу, вола стає темно-червоною із синюшним відтінком (“чорний язик”) (Мayne, 2005). Зазвичай захворювання супроводжується проносами, виявляють некротичні ентерити 3 локалізацією їх у товстому і тонкому кишечнику. В нормі вміст нікотинаміду в печінці птиці складає 160-200 мкг/г, у яйцях - 10-20 мкг/г. Повноцінний раціон для курей-несучок має містити вітаміну $\mathrm{B}_{5}$ 20-26 г/т комбікорму (Kumar \& Babu, 2009).

В6-гіповітаміноз, або недостатність піридокси$\boldsymbol{\mu} \boldsymbol{y}$ - хвороба зумовлюється недостатністю в організмі птиці вітаміну $\mathrm{B}_{6}$ або відсутністю в організмі сполук вітаміну $\mathrm{B}_{6}$, до яких належать піридоксин, піридоксаль і піридоксамін, характеризується порушенням обміну нітрогену, анемією, епілепсиформними судомами, конвульсіями, дегенеративними змінами у центральній та периферичній нервовій системі, дерматитами, особливо у ділянці черева. У курчат знижується апетит, затримується ріст, відмічаються атаксії (Salami et al., 2016). Нестача в організмі птиці вітаміну $\mathrm{B}_{6}$ порушує зв'язок білкового та енергетичного обмінів, синтез жирних кислот, знижує використання насичених жирних кислот. За його недостатності в кормах порушується синтез триптофану, метіоніну, цистину, глутамінової кислоти, колагену, який є органічною основою кісткової тканини, знижується використання та засвоєння вітаміну $\mathrm{B}_{12}$. Антагоністом піридоксину є лінамарин (лінатин), що міститься у лляній макусі. Під дією ферменту лінази він гідролізується в синильну кислоту, яка $\epsilon$ антагоністом вітаміну $\mathrm{B}_{6}$. Також вітамін $\mathrm{B}_{6}$ дуже чутливий до температури. Гранулювання комбікорму навіть за температури $85{ }^{\circ} \mathrm{C}$ призводить до руйнування його $3-5 \%$. Водночас антагоністами вітаміну $\mathrm{B}_{6} \epsilon$ дезоксипіридин, метоксипіридин та ціаноланін (міститься у плодах деяких бобових). За нестачі вітаміну $\mathrm{B}_{6}$ у сироватці крові підвищується вміст сечової кислоти. Норма вмісту піридоксину в жовтку яєць курей складає близько 3, а його білкова частина містить - 2 мкг/г. Вміст вітаміну $\mathrm{B}_{6}$ у кормах для курей залежить від віку та продуктивного напряму і в середньому становить 24 г/т (Waldenstedt, 2006).

Недостатність ціанкобаламіну (В12гіповітаміноз) виникає у птиці різних вікових груп. Вітамін $\mathrm{B}_{12}$ - це єдиний вітамін, який у своєму складі містить метал (Кобальт), амідні і ціанисті групи, тому його часто називають кобальтовмісне комплексне з'єднання - ціанокобаламін. За нестачі вітаміну $\mathrm{B}_{12} \mathrm{y}$ птиці порушується гемопоез, відновлення глутатіону, коєнзиму А, гомоцистину, пуринів та пірамідинів, біосинтез та використання амінокислот, особливо метіоніну, знижується його ліпотропна дія, зазвичай частішають випадки перозису. Клінічно В $\mathrm{B}_{12}$-гіповітаміноз проявляється втратою апетиту, зниженням росту, здебільшого низькою конверсією білкового корму, інколи виявляють проноси та запалення м'язового шлунка. У ембріонів птиці за недостатності вітаміну $\mathrm{B}_{12}$ трапляється загибель на 17-20 день інкубації, з явищами атрофії кінцівок, едемою, крововиливами, ожирінням внутрішніх органів (Halle \& Ebrahem, 2012).

Контроль забезпеченості вітаміном В $\mathrm{B}_{12}$ визначають за його вмістом у печінці, де він є у комплексі з біл- 
ками. В нормі - 230-600 мкг/кг, у жовтках яєць - 2830 мкг/кг. У складі комбікорму ціанкобаламіну має міститися 0,001-0,025 г/т (Kato et al., 2003).

Недостатність фолієвої кислоти (В гіповітаміноз) - характеризується порушенням кровотворення (найчастіше це проявляється анемією, лейкопенією), дисфункцією відтворної здатності та паралічем шийних м'язів. За нестачі фолієвої кислоти молодняк птиці погано вкривається пір'ям, перо дорослих птахів депігментується, спостерігаються слабкість кінцівок і ознаки перозу. Особливо небезпечний прояв $\mathrm{B}_{\mathrm{c}}$-гіповітамінозу буває на фоні нестачі аскорбінової кислоти, яка переводить іiі в активну форму. Надлишок протеїну та амінокислоти гліцину в раціоні годівлі курей потребує збільшення вмісту вітаміну $\mathrm{B}_{\mathrm{c}}$, оскільки виникають всі передумови до інтенсифікації пуринового обміну та накопичення солей сечової кислоти i розвитку сечокислого діатезу. Контроль забезпеченості птиці вітаміном $\mathrm{B}_{\mathrm{c}}$ здійснюють за визначенням його вмісту в яйці, який в нормі має становити не менше ніж 5, а в печінці курчат - 12 мкг/г. Повноцінні раціони птиці яєчного напряму продуктивності мають містити вітамін $\mathrm{B}_{\mathrm{c}}$ у кількості від 0,45 до 1 г/т комбікорму (Conde-Aguilera et al., 2013).

Недостатність біотину (вітаміну Н) - характеризується дерматитом, гіперкератозом, себореєю, набряками та некрозами шкіри. У птахів деформуються кістки, гальмується ріст хрящової тканини, вкорочуються і викривляються кінцівки (пероз). У курчат розвивається дерматит підошовної частини кінцівок, за тяжкого перебігу - в кутках дзьоба та повік. Шкіра підошви кінцівок стає шорсткою, мозолистою, а в подальшому тріскає, кровоточить, некротизується (Quarantelli et al., 2003).

Спостерігається висока ембріональна смертність, особливо упродовж останніх трьох діб інкубації. За нестачі біотину порушується утворення коферменту та дикарбонових кислот, які беруть участь у біосинтезі деяких білків, карбоксилування і декарбоксилування жирних кислот, синтезі ліпідів, пуринів, сечовини жирних кислот. Згодовування молодняку птиці надмірних кількостей яєць курей, качок, гусей та індиків знижує біологічну дію вітаміну Н, оскільки вони мають великий вміст біотинзв'язувального білка - авідину, який блокує біотин і перетворює його в неактивну сполуку (1 мг авідину зв'язує 13,8 мкг біотину). Найчастіше хвороба виникає за утримання птиці на пшенично-ячневих раціонах 3 добавкою термічно оброблених та автоклавованих білкових компонентів. Об'єктивними критеріями забезпеченості організму курей-несучок біотином є його вміст у яйцях курей 0,15 м кг/г та жовтку - 0,5 мкг/г. Печінка курчат у нормі містить 0,875 мкг/г біотину, за недостатності 0,29 мкг/г. Норма внесення біотину за оцінками вітчизняних вчених складає 0,11-0,15 г/т комбікорму (Larrieta et al., 2012).

Недостатність аскорбінової кислоти (вітаміну $\mathrm{C}$, протицинготний фактор) - спричиняє порушення регуляції окисно-відновних процесів вуглеводневого обміну, всмоктування заліза в кишечнику та включення його в молекулу гему, синтезу кортикостероїдів у надниркових залозах, гормонів щитоподібної, підшлункової і статевих залоз (Aengwanich, 2008). Однією iз важливих фізіологічних функцій аскорбінової кислоти є співучасть у синтезі колагену і нормалізації проникності капілярів. Нестача або відсутність його призводить до підвищення проникності і крихкості кровоносних судин, погіршується звертання крові та регенерація тканин, як наслідок - у птиці виявляють крововиливи у шкіру, видимі слизові оболонки, тканини і органи. Вітамін С у птиці синтезується в нирках (Tuleun et al., 2010). Аскорбінова кислота - могутній фактор попередження та лікування інфекційних хвороб, є природним стимулятором обмінних процесів в організмі птахів. Має також дезінтоксикаційну дію щодо багатьох промислових токсичних речовин. Промислові отрути (ртуть, свинець, миш'як, бензол і деякі інші), лікарські речовини (антибіотики тощо), а також інфекційні хвороби підвищують потребу організму у вітаміні C (Angani, 2017). Варто зазначити, що у курей-несучок дефіцит вітамінів $\mathrm{A}, \mathrm{B}_{1}, \mathrm{~K}$ та фолієвої кислоти негативно впливає на синтез вітаміну С в організмі. У нормі в сироватці крові курей-несучок міститься - 1,6-2,0 мг/100 мл (у плазмі - 0,8-1,0). Для курей-несучок віком 22-42 тижні рекомендується вносити аскорбінову кислоту в кількості не меншій за 50 г/т комбікорму (Chand et al., 2014).

\section{Висновки}

3 огляду на викладений матеріал хотілося б вкотре звернутись до читача (спеціалістів ветеринарних підрозділів). Нехтування (на перший погляд такими елементарними) заходами профілактичної безпеки як дослідження крові призводить до втрати контролю за внутрішнім середовищем організму - гомеостазом. А це своєю чергою спричиняє виникнення субклінічного (доклінічного) перебігу захворювань, коли симптоми хвороби мають неспецифічний, нетиповий характер. За відсутності належного лікування доклінічний перебіг переходить у клінічну стадію, тобто коли хвороба вже може ідентифікуватися за різними морфологічними i функціональними ознаками: 3'являються типові і навіть специфічні (патогномонічні) симптоми. Зазвичай лише за такого прояву розпочинається лікування. Але на цій стадії можуть виникати вже незворотні зміни в окремих органах та системах. У кращому разі уражені хворобою органи (печінка, нирки, органи травної системи, легені, кістки, система нейрогуморальної регуляції гомеостазу і т.д.) відновлюють свої функції лише частково. У такому випадку не можна вести мову про високу продуктивність, отримання якісної і біологічно повноцінної продукції, створення високорезистентних стад птиці та ремонтного молодняку. Чому ж не запобігти захворюванню ще на початку розвитку (субклінічна стадія)? Тоді лікувати птицю, можливо, і не доведеться, а все зведеться до використання препаратів у профілактичних дозах, які потребує іiі організм, а не застосовувати безконтрольне та безперебійне надходження лікарських засобів до організму, які не завжди діють на користь останнього. 
Відомості про конфлікт інтересів

Автори стверджують про відсутність конфлікту інтересів.

\section{References}

Abou-Elela, A. (2017). Epidemiology, pathophysiology, and management of uric acid urolithiasis: A narrative review'. Journal of Advanced Research, 8(5), 513527. doi: 10.1016/j.jare.2017.04.005.

Abudabos, A. M., Suliman, G. M., Hussien, E. O., Al-Ghadi, M. Q., \& Al-Oweymer, A. (2013). Effect of Mineralvitamin Premix Reduction on Performance and Certain Hemato-biochemical Values in Broiler Chickens. Asian Journal of Animal and Veterinary Advances, 8(5), 747753. doi: 10.3923/ajava.2013.747.753.

Aengwanich, W. (2008). Pathological Changes and the Effects of Ascorbic Acid on Lesion Scores of Bursa of Fabricius in Broilers Under Chronic Heat Stress. Research Journal of Veterinary Sciences, 62-66. doi: 10.3923/rjvs.2008.62.66.

Akbaş, Y., Yalçın, S., Özkan, S., Kırkpınar, F., Takma, Ç., Gevrekçi, Y., Güler, H. C., \& Türkmut, L. (2009). Heritability estimates of tibial dyschondroplasia, valgus-varus, foot-pad dermatitis and hock burn in broiler. Archiv fur Geflugelkunde, 73(1), 1-6.

Alloui, N., \& Bouzouaia, M. (2015). Manual of poultry diseases. Proliferative stomatitis Ulcerative stomatitis Esophagus \& Crop.

Angani, M. (2017). Ascorbic Acid Supplementation Effect on Haematology and Oxidative Stress Parameters of Broiler Chicken during the Hot-Dry Season in Southern Guinea Savannah. Journal of Poultry Research, 14(1), 28-33. URL: https://www.semanticscholar.org/paper/Ascorbic-AcidSupplementation-Effect-on-Haematology-Angani/ 26c4c0c94a622248786b3e8c0b7ee525756f2937.

Bar, A., Shinder, D., Yosefi, S., Vax, E., \& Plavnik, I. (2003). Metabolism and requirements for calcium and phosphorus in the fast-growing chicken as affected by age. British Journal of Nutrition, 89(1), 51-60 doi: $10.1079 /$ bjn2002757.

Berger, M. M., \& Shenkin, A. (2006). Vitamins and trace elements: Practical aspects of supplementation. Nutrition, 22(9), 952-955. doi: 10.1016/j.nut.2006.06.004.

Bozakova, N. A., Stoyanchev, K. T., Popova-Ralcheva, S., Georgieva, N. V., Gerzilov, V. T., \& Valkova, E. B. (2012). Behavioral study of mule ducks with subclinical muscular dystrophy under ecological comfort and stress conditions. Bulgarian Journal of Agricultural Science, 18(4), 511-518. URL: https://www.agrojournal.org/18/04-07-12.pdf.

Bradshaw, R. H., Kirkden, R. D., \& Broom, D. M. (2002). A review of the aetiology and pathology of leg weakness in broilers in relation to welfare. Avian and Poultry Biology Reviews, 13(2), 45-103. doi: $10.3184 / 147020602783698421$.

Burgos, S., Bohorquez, D., \& Burgos, S. (2006). Vitamin Deficiency-Induced Neurological Diseases of Poultry. International Journal of Poultry Science, 9(5), 804 807. doi: 10.3923/ijps.2006.804.807.
Cai, Z., Finnie, J. W., \& Blumbergs, P. C. (2006). Avian riboflavin deficiency: An acquired tomaculous neuropathy. Veterinary Pathology, 43(5), 780-781. doi: 10.1354/vp.43-5-780.

Çevík, A. (2018). Broiler Piliçlerde A Vitamin Yokluğunda Patolojik Bulgular Materyal ve Metot. Harran Üniv Vet Fak Derg, 7(2), 219-221. URL: https://dergipark.org.tr/tr/download/article-file/620117.

Chand, N., Naz, S., Khan, A., Khan, S., \& Khan, R. U. (2014). Performance traits and immune response of broiler chicks treated with zinc and ascorbic acid supplementation during cyclic heat stress. International Journal of Biometeorology, 58(10), 2153-2157. doi: 10.1007/s00484-014-0815-7.

Chen, C. Y., Lin, H. Y., Chen, Y. W., Ko, Y. J., Liu, Y. J., Chen, Y. H., Walzem, R. L., \& Chen, S. E. (2017). Obesity-associated cardiac pathogenesis in broiler breeder hens: Pathological adaption of cardiac hypertrophy. Poultry science, 96(7), 2428-2437. doi: $10.3382 / \mathrm{ps} / \mathrm{pex} 015$.

Clarke, I. (2008). Models of "Obesity" in Large Animals and Birds. Frontiers of Hormone Research, 36, 107 117. doi: 10.1159/000115359.

Conde-Aguilera, J. A. Cobo-Ortega, C., Tesseraud, S., Lessire, M., Mercier, Y., \& van Milgen, J. (2013). Changes in body composition in broilers by a sulfur amino acid deficiency during growth. Poultry Science, 92(5), 1266-1275. doi: 10.3382/ps.2012-02796.

Cortes, P. L., Tiwary, A. K., Puschner, B., Crespo, R. M., Chin, R. P., Bland, M., \& Shivaprasad, H. L. (2006). Vitamin A deficiency in turkey poults. Journal of Veterinary Diagnostic Investigation, 18(5), 489-494. doi: $10.1177 / 104063870601800514$.

Dalia, A. M., Loh, T. C., Sazili, A. Q., Jahromi, M. F., \& Samsudin, A. A. (2018). Effects of vitamin E, inorganic selenium, bacterial organic selenium, and their combinations on immunity response in broiler chickens. BMC Veterinary Research, 14(1), 249. doi: 10.1186/s12917-018-1578-x.

Dalloul, R. A., Lillehoj, H. S., Shellem, T. A., \& Doerr, J. A. (2002). Effect of vitamin A deficiency on host intestinal immune response to Eimeria acervulina in broiler chickens. Poultry Science, 81(10), 1509-1515. doi: $10.1093 / \mathrm{ps} / 81.10 .1509$.

Dinev, I. (2011). Comparative pathomorphological study of rickets types in broiler chickens. Iranian Journal of Veterinary Science and Technology, 3(1), 1-10. URL: https://iranjournals.nlai.ir/bitstream/handle/123456789 /830261/17EEA21832EB7538BDA1D97D9297ACC5 .pdf? sequence $=-1$.

Dinev, I. (2012a). Clinical and morphological investigations on the incidence of forms of rickets and their association with other pathological states in broiler chickens. Research in Veterinary Science, 92(2), 273-277. doi: 10.1016/j.rvsc.2011.02.011.

Dinev, I. (2012). Leg Weakness Pathology in Broiler Chickens. The Journal of Poultry Science, 49(2), 6367. doi: 10.2141/jpsa.011109.

Dinev, I. (2012b). Rickets: prevalence of its forms and association with other pathological conditions in broiler chickens. World's Poultry Science Journal, 
68(2), 239-243. doi: 10.1017/S0043933912000293.

Drinić, M., Kralj, A., \& Važić, B. (2016). Effects of removing vitamins and trace minerals from finisher diets on production parameters, tibia strength and ash content in chicken bones. Animal Science Papers and Reports, 34(3), 279-292.

Edwards, H. M. (2000). Nutrition and Skeletal Problems in Poultry. Poultry Science, 79(7), 1018-1023. doi: 10.1093/ps/79.7.1018.

Fan, X. Liu, S., Liu, G., Zhao, J., Jiao, H., Wang, X., Song, Z., \& Lin, H. (2015). Vitamin A deficiency impairs mucin expression and suppresses the mucosal immune function of the respiratory tract in chicks. PLoS ONE, 10(9), 1-16. doi: 10.1371/journal.pone.0139131.

Farina, G., de Mello Kessler, A., Ebling, P. D., Marx, F. R., César, R., \& Ribeiro, A. M. L. (2017). Performance of broilers fed different dietary choline sources and levels. Ciência Animal Brasileira, 18, 114. doi: 10.1590/1089-6891v18e-37633.

Fleming, R. H., McCormack, H. A., McTeir, L., \& Whitehead, C. C. (2006). Relationships between genetic, environmental and nutritional factors influencing osteoporosis in laying hens. British Poultry Science, 47(6), 742-755. doi: 10.1080/00071660601077949.

Fouad, A. M., El-Senousey, H. K., Yang, X. J., \& Yao, J. H. (2012). Role of dietary L-arginine in poultry production. International Journal of Poultry Science, 11(11), 718-729. doi: 10.3923/ijps.2012.718.729.

Greenacre, C. B. (2015). Backyard Poultry Medicine and Surgery. Edited by C. B. Greenacre and T. Y. Morishita. Hoboken, NJ, USA: John Wiley \& Sons, Inc. doi: 10.1002/9781118911075.

Hada, F., Malheiros, R. D., Silva, J. D. T., Marques, R. H., Gravena, R. A., Silva, V. K., Moraes, V. M. B. (2013). Effect of Protein, Carbohydrate, Lipid, and Selenium Levels on the Performance, Carcass Yield, and Blood Changes in Broilers. Brazilian Journal of Poultry Science, 15(4), 385-394.

Halle, I., \& Ebrahem, M. (2012). Influence of Vitamin B 12 and Cobalt on performance of laying hens. vTI Agriculture and Forestry Research, 3(62), 111-116. URL: https://iteratur.thuenen.de/digbib extern/bitv/dn050711.p df.

Hocking, P. M., Stevenson, E., \& Beard, P. M. (2013). Supplementary biotin decreases tibial bone weight, density and strength in riboflavin-deficient starter diets for turkey poults. British Poultry Science, 54(6), 801-809. doi: 10.1080/00071668.2013.860213.

Karthikeyan, K., \& Thappa, D. M. (2002). Pellagra and skin. International Journal of Dermatology, 41(8), 476-481. doi: 10.1046/j.1365-4362.2002.01551.x.

Kato, R., Bertechini, A. G., Fassani, E. J., Santos, C. D., Dionizio, M. A., \& Fialho, E. T. (2003). Cobalt and vitamin B 12 in diets for commercial laying. Brazilian Journal of Poultry Science, 5(1), 45-50. URL: https://www.scielo.br/j/rbca/a/PWpYsFcZtftXbBwYF zcCYMt/?lang=en.

Kras, R. V., Kessler, A. de M., Ribeiro, A. M. L., Henn, J. D., Bockor, L., \& Sbrissia, A. F. (2013). Effect of Dietary Fiber, Genetic Strain and Age on the Digestive Metabolism of Broiler Chickens. Brazilian
Journal of Poultry Science, 15(2), 83-90. URL: https://www.scielo.br/j/rbca/a/mw9VLXxSkQ8CBqv wh4cySfG/?format=pdf\&lang=en.

Kumar, S., \& Babu, B. V. (2009). Process intensification of nicotinic acid production via enzymatic conversion using Reactive extraction. Chemical and Biochemical Engineering Quarterly, 23(3), 367-376. URL: https://hrcak.srce.hr/40933.

Lambton, S. L., Knowles, T. G., Yorke, C., \& Nicol, C. J. (2015). The risk factors affecting the development of vent pecking and cannibalism in free-range and organic laying hens. Animal Welfare, 24(1), 101-111. doi: 10.7120/09627286.24.1.101.

Larrieta, E., de la Vega-Monroy, M. L. L., Vital, P., Aguilera, A., German, M. S., El Hafidi, M., \& Fernandez-Mejia, C. (2012). Effects of biotin deficiency on pancreatic islet morphology, insulin sensitivity and glucose homeostasis. Journal of Nutritional Biochemistry, 23(4), 392-399. doi: 10.1016/j.jnutbio.2011.01.003.

Li, X., Zhang, D., \& Bryden, W. L. (2017). Calcium and phosphorus metabolism and nutrition of poultry: Are current diets formulated in excess? Animal Production Science, 57(11), 2304-2310. doi: 10.1071/AN17389.

Lin, C. Y., Friars, G. W., \& Moran, E. T. (1980). Genetic and Environmental Aspects of Obesity in Broilers'. World's Poultry Science Journal, 36(2), 103-111. doi: 10.1079/WPS19800005.

Lin, Y. F., Tsai, H.-L., Lee, Y.-C., \& Chang, S.-J. (2005). Maternal vitamin E supplementation affects the antioxidant capability and oxidative status of hatching chicks. Journal of Nutrition, 135(10), 2457-2461. doi: 10.1093/jn/135.10.2457.

Liu, L. et al. (2015). Effect of immune stress on growth performance and energy metabolism in broiler chickens. Food and Agricultural Immunology, 26(2), 194-203. doi: 10.1080/09540105.2014.882884.

Manohar, G., \& Kanagaraju, P. (2015). Non-Infectious Form of Leg Weakness in Commercial Broilers - An Overview. International Journal of Science, Environment and Technology, 4(6), 1674-1677. URL: https://www.ijset.net/journal/823.pdf.

Mattila, P. H., Valkonen, E., \& Valaja, J. (2011). Effect of Different Vitamin D Supplementations in Poultry Feed on Vitamin D Content of Eggs and Chicken Meat. Journal of Agricultural and Food Chemistry, 59(15), 8298-8303. doi: 10.1021/jf2012634.

Mayne, R. K. (2005). A review of the aetiology and possible causative factors of foot pad dermatitis in growing turkeys and broilers. World's Poultry Science Journal, 61(2), 256-267. doi: 10.1079/WPS200458.

Mohiti-Asli, M., Shivazad M., Zaghari M., Aminzadeh S., Rezaian M., \& Mateos G. G. (2012). Dietary fibers and crude protein content alleviate hepatic fat deposition and obesity in broiler breeder hens. Poultry Science, 91(12), 3107-3114. doi: 10.3382/ps.2011-02040.

Moyle, J. R., Wideman, R. F., Whipple, S. M., Yoho, D. E., \& Bramwell, R. K. (2011). Urolithiasis in male boiler breeders. International Journal of Poultry Science, 10(11), 839-841. doi: 10.3923/ijps.2011.839.841.

Nawab, A. et al. (2018). Vitamin E and Fertility in the 
Poultry Birds; Deficiency of Vitamin E and its Hazardous Effects. Appro Poult Dairy \& Vet Sci, 5, 2-7. doi: 10.31031/APDV.2018.05.000617.

Nischemenko, M. et al. (2019). The indexes of mineral exchange in laying hens under the influence of Selenium and Zinc nonoacquahelates and vitamin E. Naukovyi visnyk veterinarnoi medycyny, (1(149)), 49-56. doi: 10.33245/2310-4902-2019-149-1-49-56.

Ognik, K., Kozłowski, K., Stępniowska, A., Szlązak, R., Tutaj, K., Zduńczyk, Z., \& Jankowski, J. (2019). The effect of manganese nanoparticles on performance, redox reactions and epigenetic changes in Turkey tissues. Animal, 13(6), 1137-1144. doi: $10.1017 / \mathrm{S} 1751731118002653$.

Oviedo-Rondón, E. O., Ferket, P. R., \& Havestein, G. B. (2006). Nutritional factors that affect leg problems in broilers and turkeys. Avian and Poultry Biology Reviews, 17(3), 89-103. doi: 10.3184/147020606783437921.

Parolini, M., Romano, M., Caprioli, M., Rubolini, D., \& Saino, N. (2015). Vitamin E deficiency in last-laid eggs limits growth of yellow-legged gull chicks. Functional Ecology, 29(8), 1070-1077. doi: 10.1111/1365-2435.12412.

Priyanka, Sharma, S., Chaudhary, R. N., Niwas R., Arora, N., \& Yadav, P. (2018). Surgical Correction of Perosis/Slipped Tendon in a White Pekin Duck- Case Report. International Journal of Current Microbiology and Applied Sciences, 7(12), 389-392. doi: 10.20546/ijcmas.2018.712.048.

Pelicia, K., Garcia, E. A., Faitarone, A. B. G., Silva, A. P., Berto, D. A., Molino, A. B., \& Vercese, F. (2009). Calcium and available phosphorus levels for laying hens in second production cycle. Revista Brasileira de Ciencia Avicola, 11(1), 39-49. doi: 10.1590/S1516635X2009000100007.

Peters, B. S. E., \& Martini, L. A. (2010). Nutritional aspects of the prevention and treatment of osteoporosis. Arquivos Brasileiros de Endocrinologia \& Metabologia, 54(2), 179-185. doi: 10.1590/s000427302010000200014.

Pineda, L. et al. (2012). Effect of silver nanoparticles on growth performance, metabolism and microbial profile of broiler chickens. Archives of Animal Nutrition, 66(5), 416-429. doi: 10.1080/1745039X.2012.710081.

Poureslami, R., Turchini, G. M., Raes, K., Huyghebaert, G., De Smet, S. (2010). Effect of diet, sex and age on fatty acid metabolism in broiler chickens: SFA and MUFA. British Journal of Nutrition, 104(2), 204-213. doi: $10.1017 / \mathrm{S} 0007114510000541$.

Proszkowiec-Weglarz, M., \& Angel, R. (2013). Calcium and phosphorus metabolism in broilers: Effect of homeostatic mechanism on calcium and phosphorus digestibility. Journal of Applied Poultry Research, 22(3), 609-627. doi: 10.3382/japr.2012-00743.

Quarantelli, A., Bonomi, A. et al. (2003). The effects of different levels of dietary biotin on the performances and on bone growth in the broiler. Italian Journal of Animal Science, 2(1), 453-455. doi: 10.4081/ijas.2003.s1.453.

Rath, N. C. Huff, G. R., Huff, W. E., \& Balog, J. M. (2000). Factors regulating bone maturity and strength in poultry. Poultry Science, 79(7), 1024-1032. doi: $10.1093 / \mathrm{ps} / 79.7 .1024$

Reznichenko, L. V., Jakovleva, I. N., Reznichenko, A. A., Denisova, N. A., Savushkina, N. G., Shevchenko, T. S., Shentseva, E. A., \& Zherebnenko, S. V. (2017). Efficiency of carotine-chlorophyllic complexes use in a-hypovitaminosis of poultry. RESEARCH RESULT. Pharmacology and Clinical Pharmacology, 3(1). doi: 10.18413/2500-235X-2017-3-1-105-113.

Romanovych, L. V., Kurtyak, B. M., Romanovych, M. S., Vishchur, O. I., \& Mudrak, D. I. (2018). Influence of vitamins $\mathrm{E}$ and $\mathrm{C}$ on the indices of pseudoeozinofiles fagocytosis in chickens broilers blood of cross ROSS308. Scientific Messenger of LNU of Veterinary Medicine and Biotechnologies, 20(92), 169-171. doi: 10.32718/10.32718/nvlvet9235.

Sakara, V., Melnyk, A., \& Markhenkov, F. (2019). State of protein and mineral exchange in broiler-chickens for the use of Zinc and Mangane chelates. Naukovyi visnyk veterynarnoi medytsyny, 1(149), 85-94. doi: 10.33245/2310-4902-2019-149-1-85-94.

Sakara, V. S., \& Melnyk, A. Y. (2019). The influence of Zinc and Manganese chelates (pantothenates) on some chicken broiler metabolism indicators. Scientific Messenger of LNU of Veterinary Medicine and Biotechnologies, 21(96), 134-140. doi: 10.32718/nvlvet9624.

Salami, S. A., Oluwatosin, O. O., Oso, A. O. et al. (2016). Bioavailability of $\mathrm{Cu}, \mathrm{Zn}$ and $\mathrm{Mn}$ from Mineral Chelates or Blends of Inorganic Salts in Growing Turkeys Fed with Supplemental Riboflavin and/or Pyridoxine. Biological Trace Element Research, 173(1), 168-176. doi: 10.1007/s12011-016-0618-2.

Selvam, R., Saravanakumar, M., Suresh, S., Chandrasekeran, C. V., \& Prashanth, D. S. (2018). Evaluation of polyherbal formulation and synthetic choline chloride on choline deficiency model in broilers: implications on zootechnical parameters, serum biochemistry and liver histopathology. AsianAustralasian Journal of Animal Sciences, 31(11), 1795-1806. doi: 10.5713/ajas.18.0018.

Sifri, M. (1995). Nutrient Requirements of Poultry, Poultry Science. doi: 10.3382/ps.0740224.

Sparke, A. J., Sims, T. J., Avery, N. C., Bailey, A. J., Fleming, R. H., \& Whitehead, C. C. (2002). Differences in composition of avian bone collagen following genetic selection for resistance to osteoporosis. British Poultry Science, 43(1), 127-134. doi: 10.1080/00071660120109962.

Swennen, Q., Decuypere, E., \& Buyse, J. (2007). Implications of dietary macronutrients for growth and metabolism in broiler chickens. World's Poultry Science Journal, 63(4), 541-556. doi: 10.1017/S0043933907001602.

Świątkiewicz, S., Arczewska-Włosek A., BederskaLojewska D., \& Józefiak D. (2017). Efficacy of dietary vitamin D and its metabolites in poultry review and implications of the recent studies. World's Poultry Science Journal, 73(01), 57-68. doi: $10.1017 / \mathrm{S} 0043933916001057$.

Tuleun, C., Njoku, P. C., \& Okwori, A. I. (2010). Effect of dietary ascorbic acid on performance of broiler chickens exposed to different lighting regime. International Journal of Poultry Science, 9(2), 118- 
125. doi: 10.3923/ijps.2010.118.125.

Waldenstedt, L. (2006). Nutritional factors of importance for optimal leg health in broilers: A review. Animal Feed Science and Technology, 126(3-4), 291-307. doi: 10.1016/j.anifeedsci.2005.08.008.

Wang, B., Zhang, X., Yue, B., Ge, W., Zhang, M., Ma, C., \& Kong, M. (2016). Effects of pantothenic acid on growth performance, slaughter performance, lipid metabolism, and antioxidant function of Wulong geese aged one to four weeks. Animal Nutrition, 2(4), 312-317. doi: 10.1016/j.aninu.2016.07.005.

Whitehead, C. C., \& Fleming, R. H. (2000). Osteoporosis in cage layers. Poultry Science, 79(7), 1033-1041. doi: $10.1093 / \mathrm{ps} / 79.7 .1033$.
Levchenko, V. I. et al. (2016). Vplyv preparatu mehavit na a-vitaminnyi i kaltsiie-fosfornyi obmin $u$ silskohospodarskykh tvaryn. Naukovyi visnyk veterinarnoi medycyny, 1, 49-56 (in Ukrainian).

Mel'nik, A. Ju. (2011). Diahnostyka ta profilaktyka vitaminno-mineralnoi nedostatnosti $\mathrm{v}$ kurei-nesuchok. Naukovyi visnyk Lvivskoho natsionalnoho universytetu veterynarnoi medytsyny ta biotekhnolohii im. S. Z. Gzhytskoho, 4(50), 284-292. URL: http://nbuv.gov.ua/UJRN/nvlnu_2011_13_4\%281\%29 55 (in Ukrainian). 